\title{
The Effect of Dental Health Education and the Total Quality Management Approach on the Behavior of Dental and Oral Health Maintenance and the Status of the Oral Hygiene Index Simplified in Elementary School Students in Aceh Besar
}

\author{
Andriani Andriani*, Ratna Wilis, Intan Liana, Cut Ratna Keumala, Sisca Mardelita, Elfi Zahara \\ Department of Dental Nursing, Polytechnic of Health, Ministry of Health, Aceh, Indonesia
}

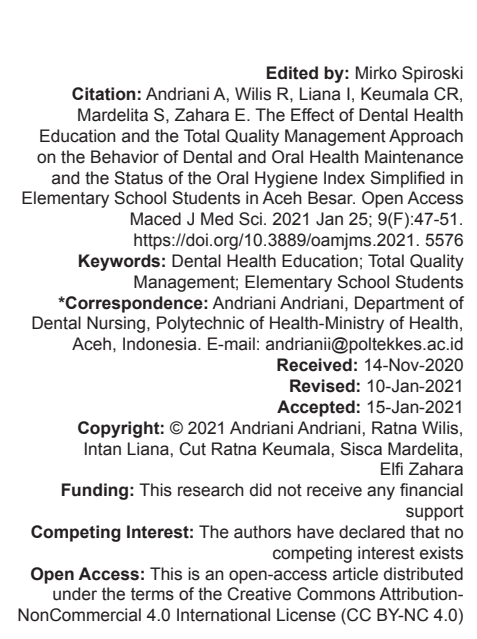

\section{Introduction}

Oral health can affect the quality of life for individuals, families, and communities [1]. Oral health and its relationship to healthy life are a multidimensional concept that includes systemic functions as well as mental and economic health [2]. Dental caries is one of the most common infectious diseases affecting all races, ages, genders, and geographic areas [3]. According to available statistics, the prevalence of dental caries among Iranian students aged 12 years is higher than the global average and, if it was left untreated, can lead to tooth loss [4]. Various factors have been identified that causes decay in children that include poor oral hygiene and nutritional status in children as well as levels of knowledge, habits, attitudes, and self-efficacy regarding oral health among school teachers and parents [5]. They are considering the critical role of teeth from various perspectives that efforts to prevent dental caries, gum disease, and tooth loss must be made. The World Health Organization recommends that every country have a regular oral health program to check oral health status every 5 years [6]. In most health-care systems, various quality improvement initiatives have been implemented to improve health-care management in general and dental health care in particular [7]. The health facilities such as hospitals and health centers as well as clinics or medical centers provide various services such as examinations, treatments, pharmacy, and laboratories. Quality management aims to continue to improve health services through quality planning, quality control, quality assurance, and quality improvement [8]. Integrated quality management is expected to help overcome various changes such as advances in technology and medical information 
systems, service systems, health plans, partnerships, alliances, and a better understanding of patients related to service quality [9]. Total quality management (TQM) is a management process through organizational behavior or culture. The TQM approach can only be achieved by paying attention to the characteristics of TQM, namely, focusing on customers/communities, obsession with quality, scientific approach, long-term commitment, teamwork, continuous system improvement, controlled freedom, unity of purpose, community involvement and empowerment, and organizing education and training. Dental health education in schools through TQM is a non-formal education system for school communities by learning by doing to change their behavior from being less profitable to be beneficial for their oral health. The goal of dental health education in schools through TQM is to change the behavior toward dental and oral health of the school community and their families from being less profitable to be beneficial for their oral health. Schools can provide a participatory and supportive environment to involve teachers and parents in the process of promoting oral health in children [10]. The results from the 2013 Basic Health Research showed that the Indonesian population had oral and dental problems by $25.9 \%$. It has been identified that $62.9 \%$ of the population in Aceh Province has caries, and generally, people brush their teeth every day in the morning shower and evening bath as much as $90.7 \%$. The proportion of people who brush their teeth every day after breakfast is only $12.6 \%$ and before sleep only $20.7 \%$. According to the results of dental and oral examinations for the 6-14 years age group in Aceh Besar District during the UKGS activity, it was shown that $34 \%$ of children had caries. The health condition of teeth and mouth in Aceh Besar District showed that the health status of teeth and mouth was a cause for concern. Based on the researcher interview with the school, it was found that the elementary school had never done dental health education through a TQM approach. The TQM approach was carried out by involving the school community, teachers, parents, and students. Based on the above background, the purpose of this study is to analyze the effect of dental education health through a TQM approach to understand the changes in dental and oral health maintenance behavior and oral hygiene index simplified (OHIS) status among students of SDN Lamsayuen, Aceh Besar District.

\section{Materials and Methods}

That type of quasi-experimental research or quasi-experimental design with pre-test research design and post-test group design was chosen. That research was conducted at Elementary School Students, Lamsayuen, Aceh Besar District. The population in this study were the principal, teachers, parents of students (mother), and all students in Grades V and VI SD Negeri Lamsayuen, Aceh Besar District, totaling 80 children. The sample in this study were the principal, teachers, and students in Grades V and VI, totaling 80 students, then divided into two groups, the intervention group consisting of 40 children was given intervention (dental health education with a TQM approach) and the control group consisted of 40 children who were not given intervention. Students were divided into two groups, namely: (1) The treatment group (I) was 20 students of class $\mathrm{Va}$ and 20 students of class VIb, a total of 40 students were given dental health education through a TQM approach. (2) The control group (II) was 20 students in class $\mathrm{Vb}$ and 20 students in class $\mathrm{Vla}$, totaling 40 students, who were not given intervention. Analysis of the results of this study using: (1) Paired samples t-test, which is to determine the differences in behavior improvement and oral hygiene status in the treatment group, namely, from pre-test to post-test I, post-test I to post-test II, and from pre-test to posttest II. (2) The independent t-test is to determine the difference in the increase in the treatment group. (3) Manova test was used to determine the effect of an intervention on maintenance behavior variables and dental and oral hygiene status. The data analysis used the Statistical Package for the Social Sciences program, with hypothesis testing based on a significant level of $p<0.00$.

\section{Results}

\section{Univariate analysis}

The univariate analysis in this study included changes in behavior and oral hygiene status OHIS before treatment (pre-test) and after treatment (posttest I and post-test II). The behavior in this study was measured using a questionnaire instrument. Meanwhile, dental and oral hygiene status data were carried out through a clinical examination of the students' oral hygiene status using the OHI-S index. The results of the univariate analysis are collected in Table 1.

Based on Table 1, the behavior results in the intervention group and the control group are in a low category $(82.5 \%)$ and the excellent category $(17.5 \%)$.

Table 1: Distribution of respondents based on behavior, and dental and oral hygiene status in Groups I and II before intervention

\begin{tabular}{|c|c|c|c|c|}
\hline \multirow{2}{*}{$\begin{array}{l}\text { Pre-test } \\
\text { Status }\end{array}$} & \multicolumn{2}{|c|}{ Group I } & \multicolumn{2}{|c|}{ Group II } \\
\hline & $\mathrm{n}$ & $\%$ & $\mathrm{n}$ & $\%$ \\
\hline Good & 7 & 17.5 & 7 & 17.5 \\
\hline Not good & 33 & 82.5 & 33 & 82.5 \\
\hline Total & 40 & 100 & 40 & 100 \\
\hline \multicolumn{5}{|l|}{ OHI-S status } \\
\hline Good & 0 & 0 & 0 & 0 \\
\hline Moderate & 11 & 27.5 & 12 & 30 \\
\hline Bad & 29 & 72.5 & 28 & 70 \\
\hline Total & 40 & 100 & 40 & 100 \\
\hline
\end{tabular}


Meanwhile, the oral hygiene status of respondents in the intervention group mostly had a lousy category of dental and oral hygiene (72.5\%), while in the control group, most of them were also in the wrong category (72.5\%).

Based on Table 2, the results of behavior in the intervention group were partly in the excellent category $87 \%$, while in the control group are in a low category of $75 \%$. The oral hygiene status of respondents in the intervention group was in the wrong category of oral hygiene $(17.5 \%)$, while the control group was in the wrong category (75\%).

Table 2: Distribution of respondents based on behavior, and dental and oral hygiene status in Groups I and II has been treated

\begin{tabular}{llllll}
\hline Post-test & Group I & & & Group II \\
Status & $\mathrm{n}$ & $\%$ & & $\mathrm{n}$ & $\%$ \\
\hline Good & 35 & 87.5 & & 10 & 25 \\
Not good & 5 & 12.5 & & 30 & 75 \\
Total & 40 & 100 & & 40 & 100 \\
OHI-S status & & & & 0 & \\
$\quad$ Good & 24 & 60 & 10 & 0 \\
$\quad$ Moderate & 7 & 17.5 & & 30 & 25 \\
$\quad$ Bad & 40 & 100 & 40 & 75 \\
$\quad$ Total & 24 & & &
\end{tabular}

\section{Testing prerequisite analysis}

Analysis of the data in this study using parametric statistical techniques t-test (paired t-test), t-test (independent t-test), and test Manova. The data normality test in this study used the KolmogorovSmirnov $Z$ test and the $F$ test (Levene's test for equality of variances). The results of the normality and homogeneity tests are as follows:

Table 3 shows that the test results with the Kolmogorov-Smirnov $\mathbf{Z}$ test, and the Levene's test on equality of variances, all of the significance are at the $5 \%$ significance level $(p>0.05)$, which means that the data in this study are typically distributed and homogeneous.

Table 3: Results of normality and homogeneity test results of data in Group I and Group II

\begin{tabular}{llll}
\hline Variable data distribution & \multicolumn{2}{l}{ Kolmogorov-Smirnov } & Conclusion \\
\cline { 2 - 3 } & $\mathrm{Z}$ & $\mathrm{p}($ sign.) & \\
\hline Behavior & 1.351 & 0.084 & Normal \\
OHI-S status & 1.19 & 0.118 & Normal \\
\hline & \multicolumn{2}{l}{ Levene's test for equality of variance } & \\
\cline { 2 - 4 } & F. Hit & $\mathrm{p}$ (Sign.) & \\
\hline Behavior & 0.236 & 0.758 & Homogen \\
OHI-S status & 1.412 & 0.364 & Homogen \\
\hline OHIS: Oral hygiene index simplified. & & &
\end{tabular}

\section{Analysis (paired sample t-test)}

The results of the analysis of the average increase in behavior, dental and oral hygiene status through pre-test to post-test I, from post-test I to posttest II, and from pre-test to post-test II in treatment Groups I and II.
Table 4 shows in the intervention group, there are differences in the average behavior of a pre-test to post-test I $(p=0.001)$. There was no difference from post 1 to post-test II $(p=1.00)$. In the intervention group, there was a difference in this status from pretest to post-test $1(p=0.001)$. Where in the control group, there was no difference in the average behavior from pre-test to post-test I and from post-test I to posttest II. There was a difference mean of status from pretest to post-test one and from post-test 1 to post-test $2(p<0.05)$ in the intervention group and the control group.

Table 4: Average of students' teeth and oral hygiene behavior and status from pre-test to post-test I, and from post-test I to post-test II, in the treatment group and the control group

\begin{tabular}{|c|c|c|c|c|c|c|}
\hline \multirow[t]{2}{*}{ Behavior } & \multicolumn{3}{|l|}{ Group I } & \multicolumn{3}{|l|}{ Group I } \\
\hline & Average \pm SD & $\mathrm{Cl}$ & $\mathrm{p}$ & Average \pm SD & $\mathrm{Cl}$ & $p$ \\
\hline $\begin{array}{l}\text { Pre-test } \\
\text { Post-test } 1\end{array}$ & $2.90 \pm 2.44$ & $3.68-2.11$ & $0.001^{*}$ & $0.25 \pm 0.27$ & $0.11-0.06$ & 0.5 \\
\hline $\begin{array}{l}\text { Post-test } 1 \\
\text { Post-test } 2 \\
\text { OHIS status }\end{array}$ & $0.00 \pm 0.22$ & $0.07-0.07$ & 1.00 & $0.50 \pm 0.22$ & $0.12-0.02$ & 0.16 \\
\hline $\begin{array}{l}\text { Pre-test } \\
\text { Post-test } 1\end{array}$ & $0.90 \pm 0.48$ & $0.74-1.05$ & $0.001^{*}$ & $0.06 \pm 0.13$ & $0.10-0.01$ & $0.006^{*}$ \\
\hline $\begin{array}{l}\text { Post-test } 1 \\
\text { Post-test } 2\end{array}$ & $0.14 \pm 0.14$ & $0.09-0.19$ & $0.001^{*}$ & $0.15 \pm 0.11$ & $0.18-0.11$ & $0.001^{*}$ \\
\hline
\end{tabular}

\section{Analysis (independent t-test)}

Based on Table 5, it shows that there are differences in behavior and oral hygiene status after dental health education through the TQM approach in students $(p<0.05)$.

Table 5: Teeth and oral hygiene behavior and status before and after being given dental health education through the TQM approach

\begin{tabular}{llll}
\hline Parameters & Mean different & $\mathrm{Cl}$ & $\mathrm{p}$ \\
\hline Education-behavior & 1.87 & $2.38-1.36$ & $0.001^{*}$ \\
Education-OHIS status & 0.56 & $0.33-0.78$ & $0.001^{*}$ \\
\hline OHIS: Oral hygiene index simplified; Note: ${ }^{*}$ = significant. & &
\end{tabular}

\section{Discussion}

The function of the teeth is as a food chewing tool, helping to crush food in the mouth to help the human general health digestive organs so the body can absorb that food. The source of oral and dental diseases in children is due to the negligence of oral hygiene, resulting in plaque accumulation. Oral health is the basis of health, quality of life and is influenced by changing individual understanding, perceptions, expectations, and the ability to adapt to circumstances [11]. The results show that there were differences in behavior and dental and oral hygiene status after dental health education through the TQM approach to students $(p<0.05)$. Dental health education that is given through the TQM approach can be realized in its actions so that it can affect the status of dental and oral hygiene. Statistically, dental health education with 
a TQM approach affects changes in behavior and OHIS status. The results of statistical tests showed that there was an effect of dental health education through a TQM approach on changes in student behavior, $p=0.001$. There is an effect of dental health education through a TQM approach to OHI-S, $p=0.01$. These findings were similar to the previous studies which concluded that implementing school health promotion programs can reduce various health problems such as smoking, low fruit, and water consumption, and bad oral health behaviors among students [12]. Trained teachers and parents play an important role in encouraging students to adopt a healthy, sustainable lifestyle for good oral health [13]. Although the oral health behavior of teachers and parents, as role models, can affect children's dental health and dental caries, it has been shown that many of these role models have limited knowledge and awareness about oral health [14]. Therefore, those groups need training and schools are ideal places that can provide a participatory environment to work on promoting children's oral health. Overall, there is limited evidence regarding the effectiveness of quality management programs in any area of health care [15]. Studies on the effectiveness of quality management programs for a dental practice can make an important contribution to the evidence base regarding quality in oral health services as well as to improve patient outcomes [16]. Continuous quality improvement is an important part of a quality management program for health-care services, which includes general medical practice and dental practice in the primary sector [17]. There is an effect of dental health education through the TQM approach on OHIS status $(p<0.05)$. Dental health education using the TQM approach influenced changes in behavior and OHI-S status $(p=0.001)$. Another study in children with special needs also concluded that oral health education could be effectively used to improve children's oral hygiene [18]. Oral health guidelines, including good dental hygiene and eating habits, can thus be an effective intervention aid for teaching basic oral health concepts among schoolchildren [19]. The results of the same study also show differences in patient satisfaction with communication according to experience and gender of dentists [20]. The results showed that in the intervention group, there were differences in the average behavior from pre-test to post-test I ( $p=0.001)$. There was no difference between post 1 and post-test II $(p=1.00)$. The control group before and after the intervention was differences in behavior which was given with a value of $p=0.001$.

\section{Conclusion}

There is an effect of dental health education through the TQM approach on OHIS status ( $p<0.05)$. Dental health education using the TQM approach influenced changes in behavior and OHI-S status $(p=0.001)$. Dental health education using the TQM approach has influenced changes in behavior and OHIS status of elementary school students in Aceh Besar districts.

\section{References}

1. Bazrafshan E, Kamani H, Kord Mostafapour F, Mahvi AH. Determination of the decayed, missing, filled teeth index in Iranian students: A case study of Zahedan city. Health Scope. 2012;1(2):84-8. https://doi.org/10.5812/jhs.5120

2. Nagarajappa R, Kakatkar G, Sharda AJ, Asawa K, Ramesh G, Sandesh N. Infant oral health: Knowledge, attitude and practices of parents in Udaipur, India. Dent Res J (Isfahan). 2013;10(5):659-65

PMid:24348626

3. Parvizi Z, Jalili Z, Masoudi G, Zareban I, Shahrakipour M. Study the knowledge, attitude and performance of the health and cure centers staff regarding using communication skills in interacting with clients in Zahedan City, 2012. Health Scope. 2013;1(4):18993. https://doi.org/10.17795/jhealthscope-7784

4. Pakpour AH, Hidarnia A, Hajizadeh E, Kumar S, Harrison AP. The status of dental caries and related factors in a sample of Iranian adolescents. Med Oral Patol Oral Cir Bucal. 2011;16(6):e822-7. https://doi.org/10.4317/medoral.17074

PMid:21196852

5. Mota A, Oswal KC, Sajnani DA, Sajnani AK. Oral health knowledge, attitude, and approaches of pre-primary and primary school teachers in Mumbai, India. Scientifica (Cairo). 2016;2016:5967427. https://doi.org/10.1155/2016/5967427

PMid:27034901

6. World Health Organization. Oral Health Surveys: Basic Methods Geneva: World Health Organization; 2013.

7. Bader JD. Challenges in quality assessment of dental care. J Am Dent Assoc. 2009;140(12):1456-64.

PMid:19955057

8. World Health Organization. Quality of Care: A Process for Making Strategic Choices in Health Systems. WHO Library Cataloguingin-Publication Data. Geneva: World Health Organization; 2006. https://doi.org/10.1108/ijhcqa.2007.06220gab.001

9. Kozak M, Asunakutlu T, Safran B. TQM implementation at public hospitals: A study in Turkey. Int J Product Qual Manag. 2007;2(2):193-207. https://doi.org/10.1504/ijpqm.2007.012410

10. Shirzad M, Taghdisi MH, Dehdari T, Abolghasemi J. Oral health education program among pre-school children: An application of health-promoting schools approach. Health Promot Perspect. 2016;6(3):164-70. https://doi.org/10.15171/hpp.2016.26 PMid:27579261

11. Glick M, Williams DM, Kleinman DV, Vujicic M, Watt RG, Weyant RJ. A new definition for oral health developed by the FDI World Dental Federation opens the door to a universal definition of oral health. J Public Health Dent. 2017;77(1):3-5. https://doi. org/10.1111/jphd.12213 PMid:28276588

12. Laurence S, Peterken R, Burns C. Fresh kids: The efficacy of a health promoting schools approach to increasing consumption of fruit and water in Australia. Health Promot Int. 2007;22(3):21826. https://doi.org/10.1093/heapro/dam016

PMid:17584783 
13. Wennhall I, Matsson L, Schröder U, Twetman S. Outcome of an oral health outreach programme for preschool children in a low socioeconomic multicultural area. Int J Paediatr Dent. 2008;18(2):84-90. https://doi. org/10.1111/j.1365-263x.2007.00903.x

PMid:18237290

14. Okada M, Kawamura $M$, Kaihara $Y$, Matsuzaki $Y$ Kuwahara S, Ishidori $\mathrm{H}$, et al. Influence of parents' oral health behaviour on oral health status of their school children: An exploratory study employing a causal modelling technique. Int J Paediatr Dent. 2002;12(2):101-8. https://doi. org/10.1046/j.1365-263x.2002.00338.x

\section{PMid:11966888}

15. Minkman M, Ahaus K, Huijsman R. Performance improvement based on integrated quality management models: What evidence do we have? A systematic literature review. Int J Qual Health Care. 2007;19(2):90-104. https://doi.org/10.1093/intqhc/ mzl071

PMid: 17277010

16. Schouten LM, Hulscher ME, van Everdingen JJ, Huijsman R, Grol RP. Evidence for the impact of quality improvement collaboratives: Systematic review. BMJ. 2008;336(7659):1491-4. https://doi.org/10.1136/bmj.39570.749884.be

PMid:18577559

17. Szecsenyi J, Campbell S, Broge B, Laux G, Willms S, Wensing $\mathrm{M}$, et al. Effectiveness of a quality-improvement program in improving management of primary care practices. CMAJ. 2011;183(18):E1326-33. https://doi.org/10.1503/ cmaj. 110412

PMid:22043000

18. Relwani $\mathrm{AH}$, Kiran $\mathrm{S}$, Bhatt $\mathrm{R}$, Patel M. Impact of dental health education on "Specific Learning Needs" children. Int J Clin Pediatr Dent. 2016;9(1):31-4. https://doi.org/10.5005/ jp-journals-10005-1329 PMid:27274152

19. Kumar Y, Asokan S, John B, Gopalan T. Effect of conventional and game-based teaching on oral health status of children: A randomized controlled trial. Int J Clin Pediatr Dent. 2015;8(2):1236. https://doi.org/10.5005/jp-journals-10005-1297 PMid:26379380

20. Waylen A, Makoul G, Albeyatti Y. Patient-clinician communication in a dental setting: A pilot study. Br Dent J. 2015;218(10):585-8. https://doi.org/10.1038/sj.bdj.2015.389

PMid:25998352 